\title{
Corporate Programs that Effectively Innovate Career Process from Professional Considered High-Performance
}

\author{
Ligia Mazurkiewicz, Karine Moraes, Otavio Silva, Luciano Junqueira \\ School of Economics and Business Administration, Pontifical Catholic University of São Paulo, São Paulo, \\ Brazil \\ (E-mail: ligiazm@br.ibm.com, karinesmoraes@yahoo.com.br, otaviotosi@uol.com.br and junq@pucsp.br)
}

\begin{abstract}
The aim of this paper is to propose a discussion about the corporative influence that programs have on high-performance careers. The study testes two assumptions: the highperformance professionals from an international IT company are directly influenced by training programs and policies to high-performance or the high-performance professionals from this company are only reinforced by training programs and policies, once technical and behavioral skills are an important part from professionals. The study is implemented with an specific company, driven by company's results in a survey on leadership, which is classified in December 2009, by HR consultancy Hewitt Associates, as the top company on leadership development. The data collection is made through a questionnaire with closed questions applied to 57 high-performance professionals from different areas, ages, and career time at the company. It is observed that high-performance professionals in this organization are reinforced by the policies, training and programs, but it is concluded that there is a large portion of personal history, studies and life choices, which make them become highperformance professionals and only training programs and policies can not arouse highperformance professions.
\end{abstract}

Key words: Career; High performance professional; Talent development programs

\section{Introduction}

Today we live in a knowledge era, which people represent a very large value for the company. Organizations have adopted new forms of work, emphasizing on performance in multi-functional teams and projects, where knowledge becomes a key factor for value creation.

Professionals in the current period are called $\mathrm{Y}$ generation or internet generation, who were born from the 80 's, and were grown in a time of great technological advances and economic prosperity. They're the successors of the $\mathrm{X}$ generation.

Used to get what they want, they have a different relationship with authority since early career and feel free to express their discontent anytime. Also fight for high wages from beginning, and are concerned about the environment and social causes.

This new generation has a different point of view from the previous generations, greater freedom of expression, worried about his personal life, wellness and personal enrichment.

"Finally, Y Generation members (born between 1978 and 1994) have come into the world connected to a global network, on line 24 hours a day, being well informed and articulate and expressing their opinions. This generation not only signals that will give continuity to the claims from previous generation, especially regarding issues of personal and professional balance, but also deepen. Generation $\mathrm{Y}$ individuals value personal goals and family above career goals - although this does not mean low organizational commitment - and they have strong intention to balance personal and professional aspects through reduced work weeks and other flexible arrangements." ${ }^{1}$

\footnotetext{
${ }^{1}$ Scalabrin, A., Kishore, A., Casado, T. Tendências na Gestão de Carreira. Gestão de Carreiras na empresa contemporânea: 209
} 
With these changes of attitudes and mentalities in labor relationship, this new scenario desserves more attention, since these changes aim more flexibility between employers and employees, and companies have realized that political and talent programs have become vital to their competitiveness in the business world.

People management took a completely different way, it's going to have an increase importance to the corporations, attract and retain qualified professionals, in order to achieve better results for company and keep them engaged and motivated at many ways.

For these reasons, this paper will give a broader focus on high performance and organizational success versus professional development programs, to check the real and effective investment from the company to this select professional group.

\section{Career Development}

If before was important for any organization the mechanical and operational intelligence to create the best ways to connect their machines, the challenge today is finding the best ways to connect their people. On this paper we try to verify whether this IT company development programs applied with high performance employees are really efficient and innovative and if they realize the programs like this and these programs actually add real value to these careers.

Besides investigating how the high-performance is influenced by the policies, training programs, we also aim to investigate whether high performance depends more on their own skills and their graduation history, than development programs from the corporation.

\subsection{Some background regarding careers today}

We are living in an era which low-skill jobs are declining and increasingly greater number of opportunities being offered to educated and skilled specialists, the knowledge workers (Robbins, 2000). The work aim is information and, as Robbins continues, the market demand for people who possess different skills, being well paid for their performance.

In this complex environment of today's globalized world, full of uncertainties, labor relations, as well as career, appearing in numerous ways, people also take responsibility for their professional development, unlike before, when the study of careers was under corporate responsibility, submitting their future to them. Currently, people sit opposite the market and build the future as the opportunities are offered to them (Dutra, 2010).

Under this challenge, the career starts to have a meaning far from a synonym of office, and therefore takes on a new concept, with features that suggest frequent changes, self innovation, autonomy, self-direction, ability to learn, ability to redirect career and life, ability to build relationships, and as a driving force the personal and psychological success. These are characteristics from protean career (Hall, 2002 apud Dutra, 2010).

Another type of career that we find in this new environment transitions, where changes are been seen at employees behavior and company itself needs to position increasingly competitive, with leaner staff, competent and exhibit greater flexibility, the boundary less career (Arthur and Rousseau, 1996 apud Dutra, 2010) could present as characteristics careers with different employers, autonomous forms supported by a network, choose the among family or others.

The boundary less careers emerged as a response to a new environment, whose social, economic and organizational have significantly influenced the career management (Dutra, 2010).

It becomes then a major challenge for the organization, as well as the area of personnel management, which seek to meet the new demands of this new professional profile, offering na attractive environment and development, looking to deploy flexible policies for basic skills development, generic and individual organization. Wood and Picarelli (2004) highlight the features of flexible companies, which stimulate the personal growth of its employees, reward 
performance and initiative, formulating challenging organizational values and vision, promotes inter-disciplinary and structures and encourage the quality of life of its employees, allow flexibility in schedules or operations, support the development of local schools, encourage participation and informal relationship between employees, provide training and education for life and seek clear communication and responsive to their employees and customers.

To achieve this greater flexibility in managing these employees, the concept and application of skills has proved vital today where knowledge, skills and attitudes, according to Dutra, combined together with value added results, has been strongly requested, developed and required by organizations. With increasingly shorter periods, lower costs and optimize profits in a highly competitive environment, the employee is perceived increasingly having to develop and focus on results and deadlines, possible through the performance of those powers.

This requires organizations to invest more in training and programs that develop their employees in order to promote the performance of these skills which will enable to achieve goals and objectives, according to the strategy proposed by the top management.

And this scenario does not reflect a change only in people development area, but also in professional attraction and selection, who has come "ready", skills that are equivalent to the defendants in order to achieve organizational goals. Farndale, Scullion and Sparrow (2010) add that we are living in an era where competition between the best employees is growing, within a scenario of expanded regional to global level, setting global talent management in a even greater importance level for the research.

For them, there are two reasons promoting this new scenario: supply and also demand increase, inside this international emerging market.

Besides this need of talent and their distinctive competencies, which enable them to work culturally and geographically on diverse environments, according to Farndale, Scullion and Sparrow (2010) to deliver the product or service will also show the importance of cognitive capital, mental models that enable them to share the knowledge in a globalized organization.

\subsection{The company approach}

Under these considerations, a study developed by Hewitt Associates, the RBL Group and Fortune magazine, which scored companies which better develop leaders around the world in 2009, evaluated this IT company in first place. Classification which motivated us, to study its high performance training capacity, indeed. (1)

According to Hewitt Associates, the main characteristics from this company about leadership development are:

"The leaders from this organization are passionate and committed. The leadership programs are practical, relevant and aligned with business objectives. Companies like this have an intense focus on talent and are deliberate about who they hire, who they train, who they promote and who is rewarded. Finally, leadership development in these organizations is an established practice and mindset." (2)

Beyond this, other four critical areas were evaluated in this corporation for being classified as "The Global Top Company for Leaders":

"The leadership remains a critical priority - in good or bad economical time, succession planning is deliberate and consistent; leaders understand clearly what is expected

\footnotetext{
(1) http://www.hewittassociates.com

(2) Maurissa, K. e Mackenzie, L. Estudo de Liderança Global localiza Empresas Top empenhadas em desenvolver líderes fortes independentemente das condições econômicas. Hewitt Associates
} 
from them as leaders, and develop the next generation of leaders is a priority." (1) For this group, high performance professionals have specific competencies, developed focus on the business needs. Bellow a summary from the HR material:

"Since its inception, this IT corporation has focused on developing the best professionals in business and technology world. With this, company gained a competitive advantage by creating and cultivating a unique kind of thinker and worker. During the past 15 years, this dedication has meant researching specific characteristics demonstrated by the bets employee behavior, features that call for skills. These skills are systematically integrated into a wide range of development processes, as they recognize the need to evolve as business needs and the world transformed. To reflect this significant change in business today, the company has identified and validated a new set of nine characteristics that describe and define the modern employee as he or she needs to behave to ensure that the company is in its best:

(1) Embrace challenge

(2) Partner for clients' success

(3) Collaborate globally

(4) Act with a systemic perspective

(5) Build mutual trust

(6) Influence through expertise

(7) Continuously transform

(8) Communicate for impact

(9) Help employees succeed

These skills reflect the updated form as the real business and the world are changing. These new approaches bring leadership and unite all existing programs of career development at this corporation, offering the employees a clearer picture of the knowledge, skills and general leadership behaviors necessary to succeed in today's market." (2)

Throughout 2010, this corporation will incorporate the new competencies in a wide range of training initiatives and employee development. They will also be part of an individual training and career development and will serve as a guide for the evaluations that comprise the annual performance evaluation from all employees, which is done by management level, based on company's business objectives.

Clearly, many efforts and financial resources are contributed by this company for making policies and different actions to this select group of employees. Adding to these existing investments, it has revamped in early 2010, its professional development program for high-performance and succession. Below is a brief description from the succession plan concept:

"The succession plan is an integrated management to the process for succession planning. The process integrates the former executive, technical resources and programs top talent, retaining many of its principles. The process of technical leadership ensures that the company has the technical talent in key positions at the right time. It also ensures a healthy succession process for key positions, ranging from those who are ready to fill leadership positions to those in training. This involves a regular assessment of professional highpotential, long-term planning focused on the development and identification of candidates for leadership positions in the future. The plan goal is to help prepare talento and leadership to fill key positions now and in future, resulting in a world class leadership team." (3)

\footnotetext{
(1) Maurissa, K. e Mackenzie, L. Estudo de Liderança Global localiza Empresas Top empenhadas em desenvolver líderes fortes independentemente das condições econômicas. Hewitt Associates

(2) Company's website

(3) Ibid
} 
This revised program is to strengthen $\mathrm{Y}$ careers organization, which this corporation strongly supports; technical leaders and business leaders, from now and the future are together in the program, a fact that in previous programs did not happen, because technical lines and business lines followed independent programs. This $\mathrm{Y}$ career format according to Dutra, 2001, provides greater levels of compensation and recognition by the company.

This company realized that the exchange of knowledge between the junctions of the $\mathrm{Y}$, is very important, since technical leaders and business leaders, develop a greater cohesion between them. Besides providing the meeting of these two distinct leadership lines, the program also aims to promote interaction between young leaders with senior leaders, thus encouraging an environment for exchanging experiences, historical, and apprentice long-term visions for the business.

Apart this succession program, the company launched in 2008 a leadership program focus on social responsibility that aims to develop leadership with focus on social responsibility and global citizenship, bellow the explanation from the website:

"This program often called a business version of the Peace Corps, addresses the 21st century context for doing business with emerging markets, diverse cultures, global teaming, complex policy environments, cross functional collaboration and increasing corporate responsibility expectations. The result is a leadership development program involving projects in growth markets working on economic, social and environmental sustainability challenges. Since the program launched in July, 2008 the program has deployed over 500 employees from 47 countries on 51 teams to Brazil, China, Egypt, India, Ghana, Malaysia, Nigeria, the Philippines, Romania, South Africa, Tanzania, Turkey and Vietnam. The experience spans six months: three months of preparatory work completed as a team, virtually, one month overseas and two months post service. All projects work at the intersection of business, technology and society. Clients include entrepreneurs, small and medium enterprises, non-profit organizations, educational institutions and governmental agencies. It's an initiative to professional development in emerging markets, based on global teaming cultures, working outside the traditional office, and increased societal expectations for more responsible and sustainable business practices. Resulting in a triple benefit:

(1) Participants benefit via a once-in-a-life time experiences, problem-solving exercise, in the developing world.

(2) Communities gain by obtaining pro bono consulting services.

(3) Company benefits by growing its next generation of leaders with the skills required to lead in a globally integrated world." ${ }^{(1)}$

\section{The IT Company - Brazil Field Study}

In order to choose the best nominees to the research, we have chosen to work with social responsibility leadership selected, once the program only select the most prepared employees among high-performance population, through extremely rigorous selection process.

Using this intentional universe data from Brazil, we reached employees who were selected in the last three years, coming from different areas in company and with quite different characteristics (ages, backgrounds, gender, tenure, etc.), making the research data well

diversified.

The methodology was based on a case study, due to been characterized as a research through collections and data records in a particular organizational environment, letting to

${ }^{11}$ Company's website 
produce a final ordered report (Chizzotti, 2003). This method allows holistic and meaningful characteristics of an event from a small group in the organizational environment are retained. (Yin, 2010).

Data from self-administered questionnaire were treated in a quantitative way, sent to each participant from the Brazilian selected (approximately 50 professionals). From these data we had 38 respondents, and interviews were conducted based on random selection (drawing $20 \%$ of participants who responded), accessing the subjective dimensions of the responses in order to make a qualitative analysis, where we seek to validate the hypotheses.

The results are presented in two phases: the first phase is the quantitative analyze from the questionnaire and the questions results, the second phase will bring the qualitative analysis, accessing the subjective dimensions of the responses.

Graph 1 brings us a clear view from the 38 respondents' age, mostly between 26 35 years. It is a group that includes many professionals from Y Generation, where the majority is female $(52.6 \%)$ which proves the equity nature treats both men and women in talent training programs for a future leader development.

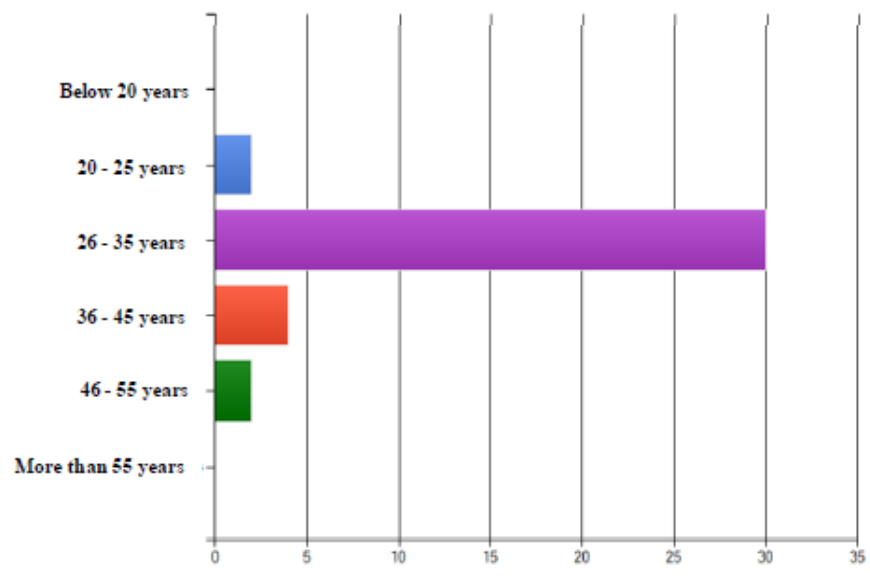

Figure 1 - The Age Analysis of Respondents

We also analyzed that these professionals between 20 and 35 years, are not yet executives, which demonstrate the company's concern to prepare the successions 10 to 15 years before it really happens.

The Table 1 characterizes the hierarchical level which these employees are:

Table 1 - The Hierarchical Level of Professionals Between 20 and 35 Years

\begin{tabular}{c|c|c|c}
\hline & \multicolumn{3}{|c}{ Age } \\
\hline & 20 to 25 years & 26 to 35 years & Response Totals \\
\hline Junior1 & $0.0 \%(0)$ & $0.0 \%(0)$ & $0.0 \%(0)$ \\
\hline Junior1 & $50.0 \%(1)$ & $0.0 \%(0)$ & $3.1 \%(1)$ \\
\hline Plain1 & $0.0 \%(0)$ & $63.3 \%(19)$ & $59.4 \%(19)$ \\
\hline Plain2 & $50.0 \%(1)$ & $36.7 \%(11)$ & $37.5 \%(12)$ \\
\hline Senior1 & $0.0 \%(0)$ & $0.0 \%(0)$ & $0.0 \%(0)$ \\
\hline Senior2 & $0.0 \%(0)$ & $0.0 \%(0)$ & $0.0 \%(0)$ \\
\hline Executive & $0.0 \%(0)$ & $0.0 \%(0)$ & $0.0 \%(0)$ \\
\hline & \multicolumn{3}{c}{ Skipped question 0} \\
\hline
\end{tabular}


Figure 2 ranks that the top performances from this corporation are between 5 and 10 years in business. The highlight that shows the importance to Y Generation, professional recognition and results in the short terms, showing that the programs offered by company actually act as an important motivating factor in attracting and retaining talent to the organization:

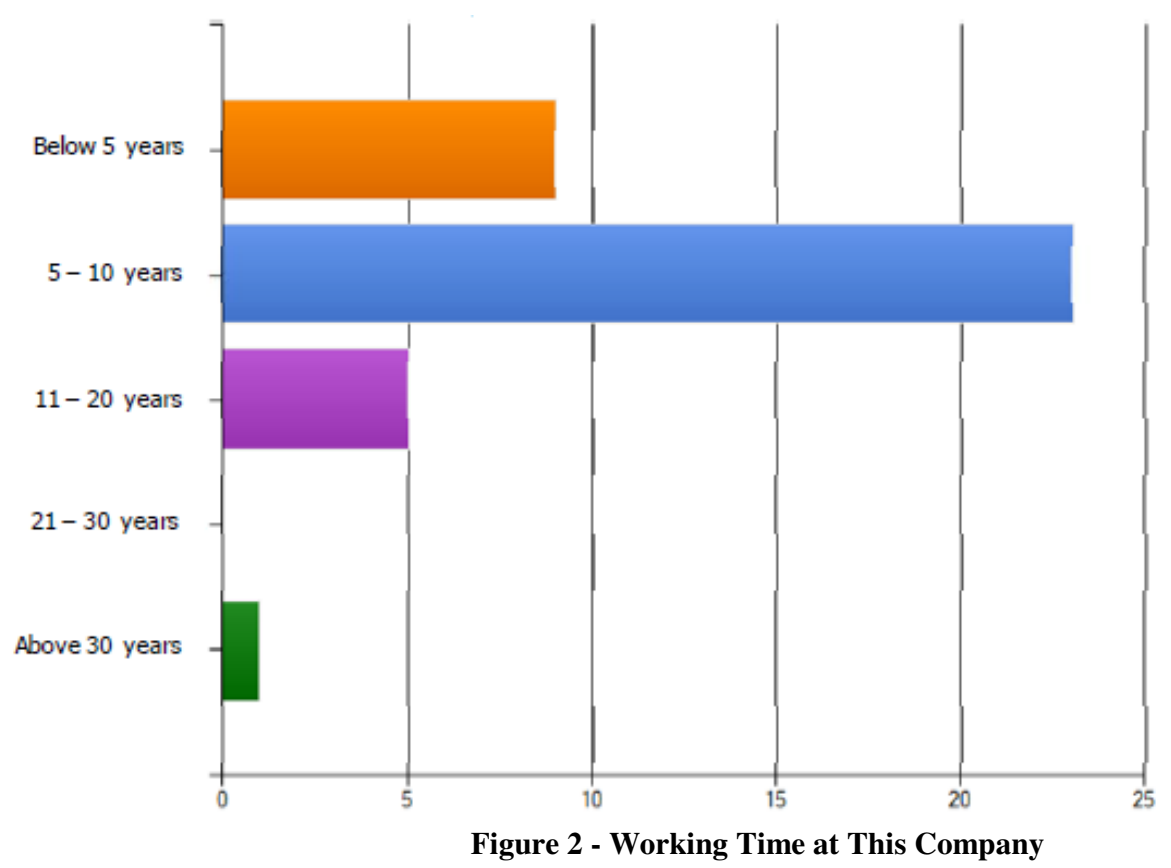

Observing Figure 3, the results demonstrates the high performance professional almost unanimous, recognized that the company offers program / policy to career development.

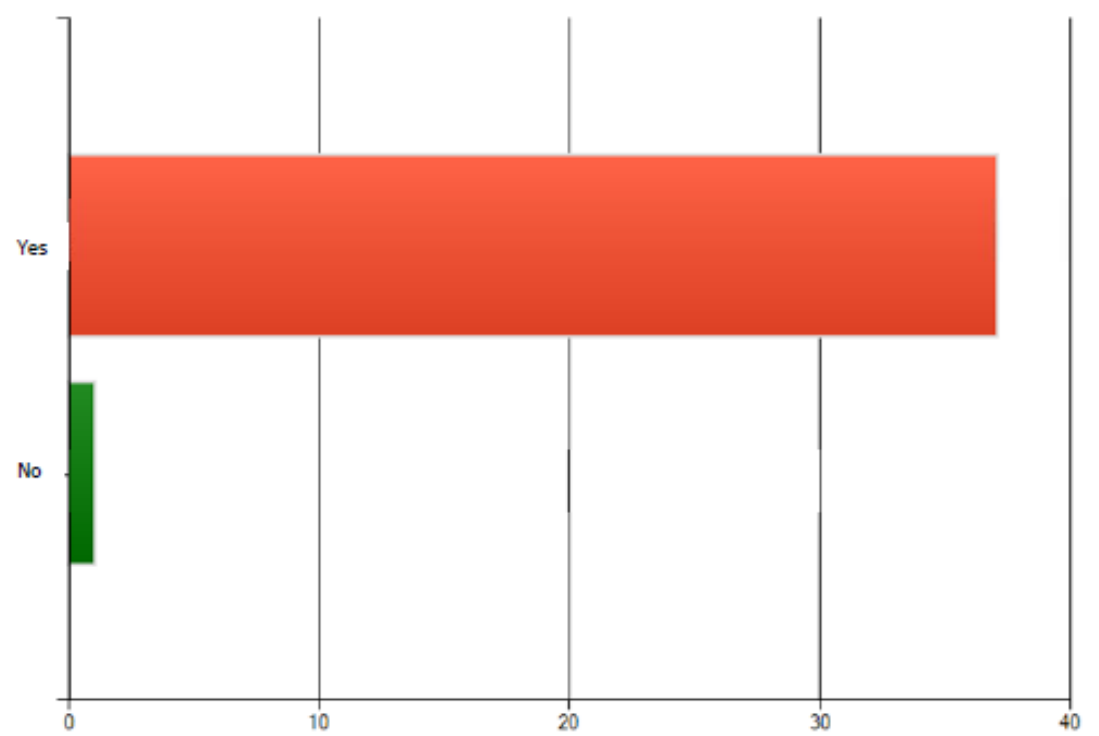

Figure 3 - Whether This Company Offers Program/Policy to Career Development for the High Performance Professional

And they recognize as great enhancers programs, as shown in Table 2, especially the leadership training program focused on Social Responsibility with $80.6 \%$ acceptance, showing it as a highly innovative and pioneering program. 
Table 2 - Which Programs/Policies Offered at the Company Really Enhanced Your Performance

\begin{tabular}{c|c|c|c}
\hline & \multicolumn{3}{|c}{ Age } \\
\hline $\begin{array}{c}\text { Leadership training program } \\
\text { focused on Career }\end{array}$ & $50.0 \%(1)$ & $26-35$ years & Response Totals \\
\hline $\begin{array}{c}\text { Lead ership training } \\
\text { program focused on Social } \\
\text { Responsibility }\end{array}$ & $100.0 \%(2)$ & $79.3 \%(23)$ & $51.6 \%(16)$ \\
\hline $\begin{array}{c}\text { Master courses } \\
\begin{array}{c}\text { Leadership training program } \\
\text { focused on Talents } \\
\text { Management }\end{array}\end{array}$ & $50.0 \%(1)$ & $31.0 \%(9)$ & $29.0 \%(9)$ \\
\hline Others & 0 replies (0.0\%) & 11 replies (37.9\%) & $35.5 \%(11)$ \\
\hline Answerd question & 2 & 29 & 31 \\
\hline \multicolumn{3}{c}{ Skipped question } \\
\hline
\end{tabular}

Professionals recognize that after being considered high-performance, their careers received differentiation, but with moderate growth. Figure 4 and table 3 characterize this information:

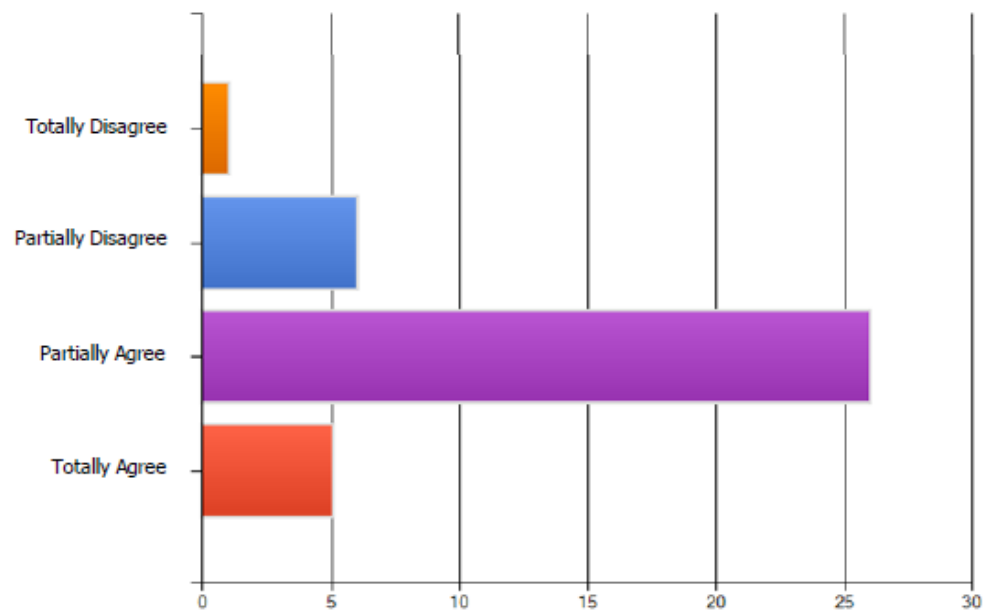

Figure 4 - Do You Recognize that after Being Considered a High-performance, Your Career Had Grow Significantly

Table 3 - How Do You Recognize that after Being Considered High-performance, Your Career Can Grow

\begin{tabular}{c|c|c|c}
\hline & \multicolumn{3}{|c}{ Age } \\
\hline & $20-25$ years & $26-35$ years & Response Totais \\
\hline Enhanced Growth & $0.0 \%(0)$ & $26.7 \%(8)$ & $25.0 \%(8)$ \\
\hline Moderate Growth & $100.0 \%(2)$ & $73.3 \%(22)$ & $75.0 \%(24)$ \\
\hline None Growth & $0.0 \%(0)$ & $0.0 \%(0)$ & $0.0 \%(0)$ \\
\hline Non Available & $0.0 \%(0)$ & $0.0 \%(0)$ & $0.0 \%(0)$ \\
\hline Comments & 0 replies & 7 replies & 7 \\
\hline Answered question & 2 & 30 & 32 \\
\hline
\end{tabular}

Skipped question 0 
At Figure 3 we presented an almost complete unanimity, that are offered programs and policies for development, which would be a strong indication or evidence that highperformance professional in the company are directly influenced and developed by training programs and company policies and not only potentiated by corporate policies and programs from the company. However, from Figure 4, we suspect a possible displacement process of understanding regarding this statement:

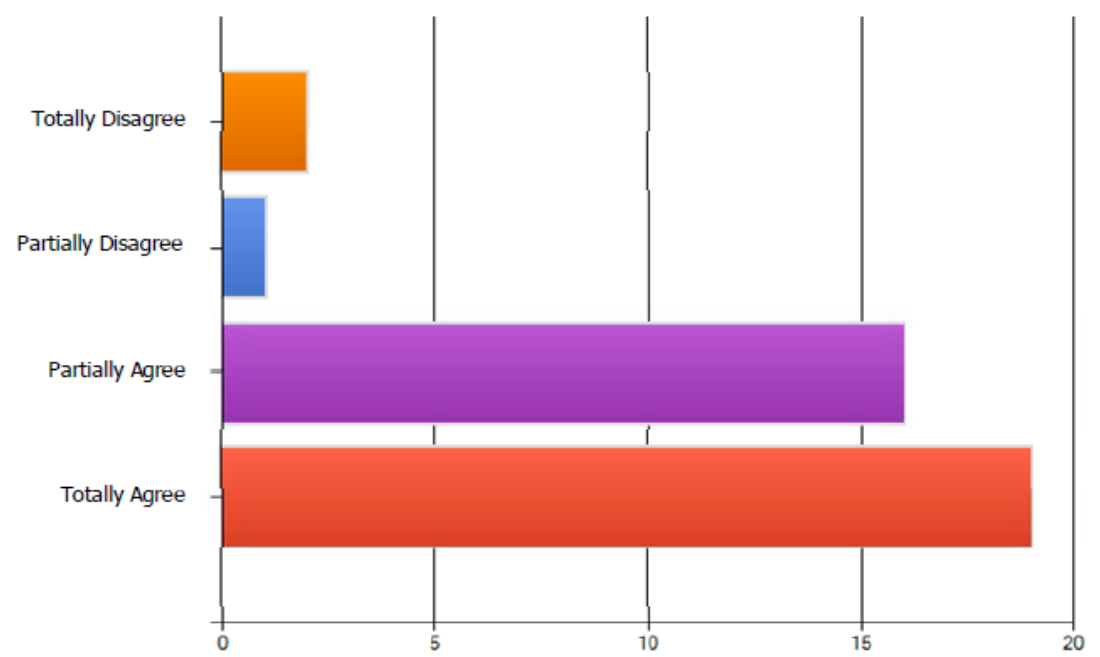

Figure 5 - Once Inside the Company, Do You Believe that the Programs are Equalitarian

When questioned whether the programs are equalitarian, we had a large number of respondents ranking "partially agree", which compelled us to call them to interview and get the real understanding of the responses. Inviting $20 \%$ respondents from the ones who answered the questionnaire, in order to test the two hypotheses:

- High Performance professionals from this IT company are directly influenced and developed by training sessions, programs and polices from the company.

- High Performance professionals from this IT company have competences and behaviors, which are only enhanced by training sessions, programs and polices from the company.

After some open questions about their backgrounds and career programs and the factors that contributed to make them high performance, we were able to unanimously support the hypothesis two since, as respondents speech were quite clear on the personal characteristics and their own initiatives that were a decisive factor in their successful career. Also they strongly recognized environment and the especial programs presents, as facilitators for their characteristics and an enhancing for their careers.

During their speech, we could noticing many characteristics from Y Generation, as they are very proactive professional with initiative, passion for what they do, and enjoying the benefits the work brings to their personal and social life.

Another factor from all respondents was the importance credited to their directed manager, supporting and guiding them, which would leverage, in their opinion, their professional development.

Overall, the set of programs and policies from this IT company was highly praised by all high-performing professional, all showing great pride and passion in what they do, showing a lot of work life balance, characterizing the fact the social responsible program was greatly appreciated by all.

At the end we gave the interviewed a chance to suggest any possible change they could add to the programs and they suggested further integration between high performance professionals as well as greater rotation among the areas to get a better understanding from all 
the processes, involving business, in order to arrive better prepared for future leadership positions.

\section{Concluding Remarks}

Our field study seems to indicate that this IT Company and its training, programs and policies directly influence the high-performance professional. But after the interview stage, we have deduced that the responses hide a basic condition; since during the interviews, it was constantly emphasized that top performers in its history played a decisive position on their high performance careers, their story was brought to this corporation and that all the personal initiatives and behaviors, can not be taught, trained and developed by any program or corporate policy without appropriate leadership.

Together with these observation we also concluded that social responsible program is an innovative tool to attract and retain top talents, even more than best compensations or best career positions, this program brought a new variable regarding a retaining talent plan, a variable that could be indentified in the interviews as world citizen leadership, from employee perspective is a possibility to somehow make a real difference in the world, not just at the corporations world, involving these talents, not just in business challenges, but also in humanitarian challenges, offering to this selected team, by giving meaning to life, a feasible reason to build their career inside the company, rather than other corporations.

\section{References}

[1] Bogdan, R.C. and Biklen, S.K. Investigação Qualitativa em Educação: uma introdução à teoria e aos métodos[M]. Porto: Porto Codex, 1994

[2] Briscoe J. P. and Hall, D.T. The Interplay of Boundaryless and Protean Careers: Combinations and Implications [J]. Journal of Vocational Behavior, 2006, 69(1): 4-18

[3] Casado, E. F. R. V., Dutra, J. S. Evolução do Conceito de Carreira e sua Aplicação para a Organização e para as pessoas. Gestão de Carreiras na empresa contemporânea[M]. São Paulo: Atlas, 2010

[4] Dutra, J. S., Gestão por Competências[M]. São Paulo: Gente, 2001

[5] Farndale, E., Scullion, H., Sparrow, P. The Role of the Corporate HR Function in Global Talent Management[J]. Journal of World Business, 2010, (45): 161-168

[6] Mairossa, K. e Mackenzie, L. Estudo de Liderança Global localiza Empresas Top empenhadas em desenvolver líderes fortes independentemente das condições econômicas. Hewitt Associates. http://www.hewittassociates.com/intl/na/enus/AboutHewitt/Newsroom/PressReleaseDetail.aspx?cid=7609. Acesso em 18 jun 2010

[7] Robbins, S. Administração: mudanças e perspectivas[M]. São Paulo: Saraiva, 2000

[8] Scalabrin, A., Kishore, A., Casadp, T. Tendências na Gestão de Carreira. Gestão de Carreiras na empresa contemporânea[M]. São Paulo: Atlas, 2010

[9] Schein, Edgar H. Career Anchors[M]. San Diego: Pfeiffer and Company, 1993

[10] Schein, Edgar H. Career Dynamics: Matching Individual and Organization Needs[M]. Reading: Addison-Wesley, 1978

[11] Vieira, M.M.F. amd Zouain, D.M. Pesquisa Qualitativa em Administração[M]. Rio de Janeiro: Ed.FGV, 2004

[12] Wood, T. e Picarelli, V. Remuneração Estratégica[M]. 3ª ed, São Paulo: Atlas, 2004

[13] Yin, R. Estudo de caso: planejamento e métodos[M]. 4a. ed, Porto Alegre: Bookman, 2010 